\title{
THE INFLUENCE OF THE INTERNET ON PREADOLESCENT STUDENT WORK HABITS FORMATION
}

\author{
Snežana Milovanović ${ }^{1}$ \\ Veljko Aleksićz* \\ 1O.Š."Filip Filipović", \\ Čačak, Serbia \\ 2University of Kragujevac, \\ Faculty of Technical Sciences, \\ Čačak, Serbia
}

\begin{abstract}
:
The constant development of new technologies and internet services, and above all their wide availability, have contributed to modernization in all spheres of life and work. As digital competencies became part of everyday life and work, their constant development is necessary. Teachers are expected to know modern concepts, methods and educational tools, and students to be active participants in the teaching process. Having in mind the advantages that modern technology brings with it, we cannot ignore the numerous negative consequences it leaves on all generations. Younger children and children of school age are especially susceptible to this. With the development of technology, the ways of teaching and learning are also changing. Therefore, care should be taken about the measure and manner of using ICT in teaching and. The results of research conducted on a sample of 359 preadolescent student shown what impact new technologies have on this population and the extent to which their work habits have changed..
\end{abstract}

Keywords:

working habits, preadolescents, internet, learning.

\section{INTRODUCTION}

Technology development has led to significant structural changes in the life and work of all of us. It has a special impact on children, preadolescents and adolescents, who encounter the Internet and various digital media from early age. This leads to disturbances in the relationship between adults and children, but also children among each other. Uncontrolled of poorly controlled technology access can lead to various negative consequences that can be manifested through irritability, anxiety or attention deficit disorder. This can also lead to conflicts between children and their parents due to the denial using ICT devices for a longer period of time. The younger children are, the more control parents have over the use of digital technologies in order to ensure the safety of children and to prevent possible negative behavior. The older children get, the more parents lose control over the digital content that children absorb every day and activities they undertake.
Correspondence:

Veljko Aleksić

e-mail:

veljko.aleksic@ftn.kg.ac.rs 
Digital technology has already changed our worlds, the way we think and conclude or find solutions. As children and young people are the most active users of digital technologies, the greatest impact on their growth and development there is. All this leads to changes in the way of learning, organization and formation of work habits. It is becoming increasingly difficult for students to resist the influence of video games and other digital interactive content provided online. Due to that, but also a number of other factors, students quickly lose motivation to learn. There is a growing problem of decreased concentration and maintaining continuity in learning. Most of the children do not develop the habits of self-controlled learning or engaging in some physical activity on their own, and it became necessary to initiate these activities by their parents. With a change in the way of thinking, there clearly are changes in the way of behaving.

\section{THEORETICAL FRAMEWORK}

Digital literacy is one of the eight key competencies for lifelong learning and a necessary prerequisite for the personal development of each individual in today's society [1]. Young people are the backbone of today's information society due to the fact that over $80 \%$ of population aged between 15 and 24 use the Internet [2]. As digital technologies have become an integral part of everyday life, today's generations of students spend most of their free time with computers or smartphones. The concept of extracurricular teaching in the digital environment can be one of the possible solutions to alleviate this imbalance and often inadequate use of technology [3]. The concept of this model is to encourage student creativity, development of critical thinking, better communication, research and problem solving. The use of modern technologies in the teaching process should contribute to the support of different learning styles of students, timely feedback and a safe learning environment. The introduction of mobile technologies in teaching activities further enables beforementioned model. Taking into account the fact that about $84 \%$ of fourth grade students and as many as $94 \%$ of eighth grade primary school students in Serbia have a mobile phone [4], the potential for using mobile applications as modern teaching aids is becoming more than real. This has proven to be very useful during the state of emergencies (e.g. Covid-19 pandemic) as learning facilities are available to students at any time and in any place.
This enables alternate means of communication with teachers and timely feedback. In addition to communicating and sharing content via Viber, Google Classroom, Microsoft Teams, Zoom, Skype, etc., students can follow the lessons through TV broadcasts, access the content online and review it at any time of the day [5]. Nevertheless, parents should monitor and direct activities in order to maintain learning continuity and in order to prevent neglect of work obligations.

The importance of using ICT in modern learning is immeasurable, as it encourages an active approach of students, arouses interest, develops independence and cooperation, but also develops skills of using digital resources in the function of learning. According to Blum's assessment, cognitive characteristics have the largest share in school achievement (50\%), followed by affective characteristics (25\%) and teaching quality (25\%) [6]. Operationalized outcomes of the educational process, and especially teaching, are precondition for improving the teaching process, directing the teaching activities and also enabling students to recognize the goals and purpose of their learning consciously and actively. This facilitates self-regulated learning and encourages the development of cognitive strategies that are the basis of better school achievement [7]. Taking into account the individual differences of students and their ways of learning, we can create an environment in which they have the opportunity to feel important through discussion, searching for answers and solutions and incorporating their own knowledge and experience. In this way, students become active participants in teaching, equal to the teacher, and learning is then perceived as a process in which information circulates among each other [8]. A student who has developed work habits and has a high level of independence can apply various strategies and skills that enable selection, comparison of information and their connection with already acquired knowledge. Students continuously acquire knowledge and develop their personality through cooperation and the activity itself becomes an internal motivation and reward. By introducing innovations in teaching methodology, the formation and development of work habits is also changed.

The 2018 PISA assessment report shown that every third student in Serbia does not reach the basic level of literacy [9]. In relation to previous assessments, the fact is that our educational system and applied strategies have not made significant progress. As learning through experience is the fastest way to acquire functional knowledge, the aim should be introducing new teaching methods and procedures that contribute to this. 
By applying collaboration, project teaching, research and problem-based learning, students should handle various procedures to achieve results while strengthening skills in the field of digital technologies.

\section{The role of teachers in encouraging student activities}

The development of student digital competencies depends on the levels of competencies of teachers and their readiness to innovate. The application of modern digital tools offers opportunities and potentials for increasing students' interest. However, excessive use of educational technology can lead to a counter-effect - lack of interest, feelings of boredom or inattention. As technology develops over time, so does the ways in which it can be used in teaching, with care being taken about the moderate use and adequate harmonization of learning content with students age [10]. When we analyzed the educational systems that achieved the best results in the PISA assessment, we concluded that these countries are careful with the introduction of technology into the teaching process. Students who make extensive use of technology performed worse than those who use technology sparingly [10]. Therefore, large investments of certain countries in the introduction of technology in education with the reason that it will contribute to the improvement of students' knowledge are not justified. It is necessary to implement existing educational technology better in order to improve the quality of learning. The teacher must create classes so that the teaching is dynamic and innovative, relying on his/her knowledge, abilities and imagination, and at the same time taking into account the goals, as well as the characteristics of students and the conditions in which he/she works [11].

In addition to formal education, students lear in other places as well in their free time. These activities are supplemented by multimedia technology, so in that sense, the school would have to intensify cooperation with parents and direct students to quality use of free time [12].

\section{The influence of the family on school success}

The family is the most important part of children lives in which they acquire the first knowledge, skills and habits. In addition to encouraging emotional and social development, one of the important goals of family education is to help and encourage the child in intellectual development and the development of personal learning potential. Children who are encouraged by their parents and who are involved in various activi- ties and forms of learning, both in and out of school, show greater achievements. In the phase of developing creative abilities, parents have a great responsibility to create a learning environment that will also support motivation. Therefore, it is necessary for parents to show self-confidence, positive attitudes towards learning, high expectations of themselves and their children, as well as interest in the child's success. The child must have freedom, but also the rhythm of the day, predictability, established habits.

If there is a strong affective connection between the child and the parents, learning is very intense and spontaneous, takes place through everyday social relationships, and the child's motivation is very strong [13]. The family must provide the child with the most positive examples of behavior in life, constructive solving of real problems, gradually burden it with greater duties and responsibilities in accordance with the degree of physical and mental development.

\section{The influence of modern technologies}

Exposure to digital content begins very early in age and reaches its peak in adolescence where it is noted that students spend an average of about 4 hours a day consuming digital media [14]. It is noticeable that each succeeding generation acquires greater digital literacy than its predecessors, and each succeeding one shows a greater capacity for digital expression [15]. It cannot be said that the growing prevalence of the Internet among the younger population is not worrying. As many as $8.2 \%$ of the total population of the Western world has some form of digital addiction [16]. The application of multimedia and the Internet in teaching enables individualization and progress of students depending on their prior knowledge and interests, unlimited repetition of given content, organization of cooperative-interactive learning, management of the learning process, easier access to different sources of knowledge, easier insight into different views of a problem and feedback [17]. Researchers are unique in stance that it is not important how long young people use the computers and/or the Internet, but how they use it.

The results of research conducted in Serbia [4] show that the use of digital devices and the Internet is widespread among students, as well as that the availability and frequency of use increase with the age of students. In the same research, almost two thirds of the surveyed students state that their parents have weaker digital skills compared to theirs and therefore do not view them as partners in digital communication. 
Also, research shows that parents are more knowledgeable and more likely to mediate in the activities of girls than boys, and that they rarely use technical protection measures, i.e. "parental control" in order to ensure the safety of children online, much less often than in other countries [18]. Experts believe that a total ban is not an effective method against excessive use of Internet services, but that more frequent conversations with children, warning them of the dangers of excessive computer use and motivating them to engage in physical activity is [16].

\section{RESEARCH METHODOLOGY}

The research problem was estimating the work habits of upper grade primary school students and the impact of technological changes on their motivation and learning. The research covered different social, material and demographic motives that influence the learning and teaching processes, as well as different preferences of preadolescent students.

The research was realized by non-experimental method of surveying students at school. A questionnaire was developed for the purpose of the research. IBM SPSS Statistics v22 was used for data processing. The research was conducted in three primary schools in the area of Čačak and Gornji Milanovac, on a sample of fifth, sixth and seventh grade students.

\section{Hypotheses}

Basic hypothesis was that preadolescent students have developed online working habits.

Hypothesis H1: Students actively participate in teaching and are able to connect new material with materials from other subjects and see the connection between related subjects.

Hypothesis H2: Students engage in sports activities in their free time and spend time in nature.

\section{RESULTS AND DISCUSSION}

A total of $N=359$ students participated in the research, of which $\mathrm{N}=179$ (49.9\%) boys and $\mathrm{N}=180$ girls (50.1\%). The structure of the sample according to grades and sex is shown in Table 1.

\begin{tabular}{|c|c|c|c|c|c|c|}
\hline \multirow{2}{*}{ Grade } & \multicolumn{4}{|c|}{ Gender } & \multirow{2}{*}{ Total } & \multirow{2}{*}{$\%$} \\
\hline & Male & $\%$ & Female & $\%$ & & \\
\hline $5^{\text {th }}$ & 51 & 14,2 & 48 & 13,4 & 99 & 27,6 \\
\hline $6^{\text {th }}$ & 66 & 18,4 & 79 & 22,0 & 145 & 40,4 \\
\hline $7^{\text {th }}$ & 62 & 17,3 & 53 & 14,7 & 115 & 32 \\
\hline Total & 179 & 49,9 & 180 & 50,1 & 359 & 100 \\
\hline
\end{tabular}

Table 1. Structure of the sample by gender

Based on the processed data, it can be concluded that the largest number of students live with one sister $\mathrm{N}=$ 120 (33.5\%) or with one brother $\mathrm{N}=97$ (27.1\%), while 49 students (13.7\%) do not even have brother or sister, and 40 students (11.2\%) live in a community with one brother and one sister, as in Table 2.

\begin{tabular}{|c|c|c|c|c|c|c|c|c|c|c|}
\hline \multirow{2}{*}{ 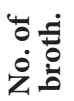 } & \multicolumn{8}{|c|}{ No. of sisters } & \multirow[b]{2}{*}{ Tot. } & \multirow[b]{2}{*}{$\%$} \\
\hline & 1 & $\%$ & 2 & $\%$ & 3 & $\%$ & Null & $\%$ & & \\
\hline 1 & 40 & 11,2 & 5 & 1,4 & 3 & 0,8 & 97 & 27,1 & 145 & 40,5 \\
\hline 2 & 6 & 1,7 & 1 & 0,3 & 0 & 0 & 18 & 5 & 25 & 7 \\
\hline 3 & 3 & 0,8 & 0 & 0 & 0 & 0 & 2 & 0,6 & 5 & 1,4 \\
\hline Null & 120 & 33,5 & 14 & 3,9 & 0 & 0 & 49 & 13,7 & 183 & 51,1 \\
\hline Tot. & 169 & 47,2 & 20 & 5,6 & 3 & 0,8 & 166 & 46,4 & 358 & 100 \\
\hline
\end{tabular}

Table 2. Family structure of the sample

By processing the obtained results, it can be concluded that the largest number of the surveyed students used the Internet over two hours per day (34.3\%), which is an extremely high percentage among the younger population, as shown in Table 3. We concluded that both boys and girls use the Internet equally without major deviations. Further analysis shown that the frequency of Internet use increased with age. There were no statistically significant differences according to the gender of preadolescents in relation to the average daily internet use $(\mathrm{t}(352)=1.397 ; \mathrm{p}=0.163)$.

\begin{tabular}{ccc}
\hline Time & Frequency & Percent (\%) \\
\hline 30 minutes & 35 & 9,7 \\
\hline 1 hour & 102 & 28,4 \\
\hline 2 hours & 94 & 26,2 \\
\hline Over 2 hours & 123 & 34,3 \\
\hline Total & 354 & 98,6 \\
\hline
\end{tabular}

Table 2. Time spent on the internet

By analyzing the results of our research, we came to the conclusion that preadolescents used the Internet mainly for playing games, entertainment and communication. 
$50.7 \%$ of students said that they used the Internet as a source of knowledge. There was a statistically significant difference in the analysis of Internet use for play among preadolescent students in relation to male $(\mathrm{M}=0.77$; $\mathrm{SD}=0.425)$ and female $(\mathrm{M}=0.38$; $\mathrm{SD}=0.486)$ gender; $(\mathrm{t}(357)=8,040 ; \mathrm{p}<0.001)$. Boys used the Internet to a much greater extent for gaming, while girls used it for communication. Similar results were obtained in a study conducted by the Institute of Psychology [4]. Student activities on the Internet were divided into three groups: communication, entertainment and finding information. According to the obtained data, boys more often used the Internet as a form of entertainment and were more skilled in using the Internet.

When asked if they study every day, $58.7 \%$ of students said they did not have that habit, while $41.3 \%$ of students answered affirmative. An independent sample t-test was conducted to compare students' daily learning habits. There was a significant difference in male (M $=1.67 ; \mathrm{SD}=0.471)$ and female $(\mathrm{M}=1.50 ; \mathrm{SD}=0.501)$ gender; $(\mathrm{t}(352.1)=3.248 ; \mathrm{p}=0.001)$.

It was concluded that the largest number of students have developed work habits when solving homework $68.3 \%$ stated that they perform their work tasks in an organized manner, during the day, 19.3\% do tasks immediately after school, $12.4 \%$ at night before bed, and a small number of students stated that they did not do their homework, as shown in Table 4.

\begin{tabular}{|c|c|c|c|c|c|c|}
\hline \multirow{2}{*}{ Homework... } & \multicolumn{4}{|c|}{ Gender } & \multirow{2}{*}{ Total } & \multirow{2}{*}{$\%$} \\
\hline & Male & $\%$ & Female & $\%$ & & \\
\hline $\begin{array}{l}\text { right after } \\
\text { school }\end{array}$ & 28 & 8,1 & 39 & 11,2 & 67 & 19,3 \\
\hline $\begin{array}{l}\text { in the evening } \\
\text { before sleep }\end{array}$ & 22 & 6,3 & 21 & 6,1 & 43 & 12,4 \\
\hline during the day & 119 & 34,3 & 118 & 34 & 237 & 68,3 \\
\hline Total & 169 & 48,7 & 178 & 51,3 & 347 & 100 \\
\hline
\end{tabular}

Table 4. Homework habits by gender

It is interesting that with age, students change their work habits, so in older grades, the number of students who finished their obligations at the end of the working day before going to bed increases, and the number of those who finished those obligations immediately after school decreases. The t-test confirmed that there was no significant difference in analysis for male $(\mathrm{M}=2.54$; $\mathrm{SD}$ $=0.764)$ and female $(\mathrm{M}=2.44 ; \mathrm{SD}=0.830)$ sex; $(\mathrm{t}(345)$ $=1.104 ; \mathrm{p}=0.271)$.
The largest percentage of the examined sample had a habit of learning immediately before the exams (43.2\%) and on weekends $(40.1 \%)$, while learning is practiced every day by a much smaller number of students (28.7\%), as shown in Table 5. However, a fairly large number of students stated that they usually study before the end of the school year. By reviewing the obtained results, we can see that girls show a greater interest in acquiring knowledge regularly every day and on weekends.

\begin{tabular}{ccccc}
\hline \multirow{2}{*}{ Learning... } & \multicolumn{2}{c}{ Gender } & \multirow{2}{*}{ Total } & $\%$ \\
\cline { 2 - 3 } & Male & Female & & \\
\hline $\begin{array}{c}\text { at the beginning } \\
\text { of schoolyear }\end{array}$ & 36 & 39 & 75 & 20,9 \\
\hline $\begin{array}{c}\text { before trimester } \\
\text { before testing }\end{array}$ & 19 & 21 & 40 & 11,1 \\
\hline $\begin{array}{c}\text { at the end of } \\
\text { schoolyear }\end{array}$ & 43 & 83 & 155 & 43,2 \\
\hline weekend & 59 & 85 & 144 & 40,1 \\
\hline every day & 39 & 64 & 103 & 28,7 \\
\hline
\end{tabular}

Table 5. Learning continuity by gender

The largest number of students (34.8\%) stated that they were most motivated to get a good grade, while $10.9 \%$ of students stated that their parents motivate them the most to learn. A certain number of students (12.3\%) believe that they are best motivated to be educated and acquire new knowledge. As many as $11.4 \%$ of students stated that they do not know what motivates them to learn or that there is no motivation.

We asked students how much time they spend learning, and by analyzing their answers we concluded that most students need about two hours to master the new teaching material $(40.1 \%)$. One hour is enough for a large number of students $(27.4 \%)$, and a significant number of students need three hours or more (20.5\%). There was a statistically significant difference in the analysis of the time required for learning in relation to male $(\mathrm{M}=2.47 ; \mathrm{SD}=0.884)$ and female $(\mathrm{M}=2.93$; $\mathrm{SD}$ $=0.923)$ gender $(\mathrm{t}(315)=-4.557 ; \mathrm{p}<0.001)$. Boys need significantly less time to learn, or are still less interested in learning than girls. A large number of girls stated that they need two to three hours to acquire knowledge.

The following data proves that concentration has a great influence on the speed of learning and memory. As many as $65.8 \%$ of the surveyed sample stated that they cannot fully concentrate on learning when other people are in the room where they are studying. The presence of others distracts girls and boys alike, without exception. 
A smaller but not insignificant number of students (34.2\%) confirm that they can learn and that other people in the room do not interfere with their learning. Using the t-test, it was found that there were no statistically significant differences in the analysis in relation to male $(\mathrm{M}=1.61 ; \mathrm{SD}=0.490)$ and female $(\mathrm{M}=1.71 ; \mathrm{SD}$ $=0.456)$ gender; $(\mathrm{t}(352)=-1.987 ; \mathrm{p}=0.048)$.

A little over half of students (55.2\%) understand the material they are learning and occasionally compare it with similar material from other subjects. Using the $\mathrm{t}-$ test, it was found that there was no significant statistical difference in relation to male $(\mathrm{M}=1.43 ; \mathrm{SD}=0.496)$ and female $(\mathrm{M}=1.47 ; \mathrm{SD}=0.500)$ gender, $(\mathrm{t}(355)=-0.802$; $\mathrm{p}=0.423)$. However, there is a large number of those who do not notice the connection between the subjects $(44.8 \%)$ and do not connect the new with the already learned material from other subjects.

By examining the procedures that students used when solving homework, it was found that $61.8 \%$ of students used the logic and memory of the material from the class when solving tasks, and then check the procedure and solution. A certain number of students (38.2\%) first remember what they did in class, check the procedure, and then solve the planned tasks. Also, most students who rely on logic and memory, solve their obligations and homework during the day, while a small number of students postpone obligations until they go to sleep. The T-test did not show a statistically significant difference between male $(\mathrm{M}=1.64 ; \mathrm{SD}=0.482)$ and female $(\mathrm{M}=1.60$; $\mathrm{SD}=0.492)$ gender, $(\mathrm{t}(344)=0.768 ; \mathrm{p}=0.443)$.

The analysis of the obtained data showed that the repetition of already learned material is the easiest way for students to learn as $57.1 \%$ of students chose this way of learning as the most effective method in learning (Table 6). Practical work, homework and research on the Internet are equally represented among students from fifth to seventh grade, with minor deviations. It turned out that practical work and research on the Internet were more suitable for boys, while repetition of materials was most suitable for girls.

\begin{tabular}{ccccc}
\hline \multirow{2}{*}{ Learning... } & \multicolumn{2}{c}{ Gender } & Total & $\%$ \\
\cline { 2 - 3 } & Male & Female & & \\
\hline by practice & 49 & 31 & 80 & 22,3 \\
\hline $\begin{array}{c}\text { by doing } \\
\text { homework }\end{array}$ & 43 & 44 & 87 & 24,2 \\
\hline $\begin{array}{c}\text { by repetition } \\
\text { by exploring on } \\
\text { the Internet }\end{array}$ & 50 & 125 & 205 & 57,1 \\
\hline
\end{tabular}

Table 6. Most efficient knowledge acquirement
When we talked about the teaching aids that students prefer using while acquiring new knowledge, we concluded that the largest number of students used a textbook as the most dominant tool (78\%), while $67.7 \%$ used a notebook. Internet content is less present among students only $19.5 \%$. Observing the gender characteristics of students, it can be concluded that both girls and boys mostly used textbooks and notebooks, and notebooks were more important source of knowledge among girls.

According to their statements, the largest number of students who participated in this research spent their free time playing outside (32.3\%). A significant number of students (27.8\%) spend their free time with friends, as well as using the phone, computer and the Internet (22.8\%).

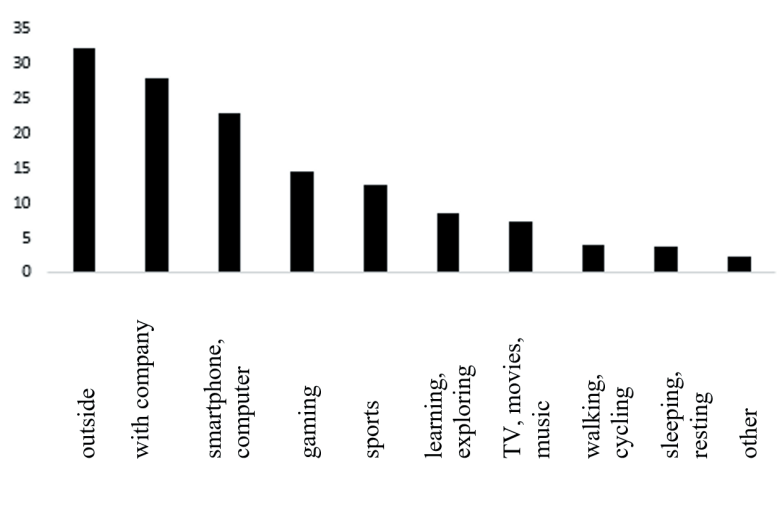

Fig. 1. How students spent their free time.

\section{CONCLUSION}

The research confirmed the basic hypothesis that preadolescents developed working habits of learning via the Internet. Their use of ICT is not primarily focused on the learning, but often for communication, entertainment and research in order to acquire certain knowledge. However, the results show that $50.7 \%$ of students used the Internet to learn. It was concluded that as many as $99.7 \%$ of students had access to the Internet, and that only 9.7\% of students used it every day for up to half an hour. However, the largest number of students who used modern technologies was over two hours per day (34.3\%).

The assumption that students take active part in the teaching process and are able to connect new material with materials from other subjects turned out to be correct, which confirmed hypothesis H1. Students stated that they actively participated in teaching (77.9\%) and $55.2 \%$ answered that they understood and connected the material they were learning. 
The $\mathrm{H} 2$ hypotheses that students engaged in sports activities in their free time and spent time in nature has been confirmed. The largest number of students (32.3\%) stated that they spent their free time in nature and $12.5 \%$ of the examined sample were engaged in sports. However, it is surprising that a large number of students did not engage in any sports activity (34.5\%). Sports activities and recreation are especially important for the proper growth and development of students, especially in preadolescent age.

We can conclude that technological progress greatly changed the roles of both teachers and students. Children should be provided with the most stimulating learning environment possible. Parents are expected to encourage, or at least not hinder the development of their child's abilities, interests and creativity. The school must adapt to changing requirements, and it has a great responsibility to support the positive attitude of students towards learning, to help them develop effective learning strategies and strengthen their interests. Guided by the iceberg metaphor, we can conclude that learning that takes place in schools and other educational institutions makes up 20\% of the visible part above water, while self-organized learning makes up the remaining $80 \%$ below water. Although working habits and learning strategies are changing, educational technology can under no circumstances replace teachers in the learning process. Digital games and other multimedia content have many advantages as they lead to acquiring logical skills, develop problem-solving strategies, set and achieve goals.

\section{REFERENCES}

[1] Carretero, S., Vuorikari, R., Punie, Y. (2017). The Digital Competence Framework for Citizens. Publications Office of the European Union. Posećeno u avgustu 2018., https://publications.jrc. ec.europa.eu/repository/bitstream/JRC106281/webdigcomp2.1pdf_(online).pdf

[2] Kuzmanović D. (2017). Empirijska provera konstrukta digitalne pismenosti i analiza prediktora postignuća. Doktorska disertacija. Beograd: Filozofski fakultet.

[3] Ristić M., Blagdanić S. (2017). Nove perspektive u obrazovanju - vanučionička nastava u digitalnom okruženju. Inovacije u nastavi - časopis za savremenu nastavu, 30(2), str. 1-14. DOI: 10.5937/inovacije1702001R

[4] Popadić D., Kuzmanović D. (2016.). Mladi u svetu interneta: korišćenje digitalne tehnologije, rizici i zastupljenost digitalnog nasilja među učenicima u Srbiji. Beograd: Ministarstvo prosvete nauke i tehnološkog razvoja Republike Srbije, UNICEF
[5] Politis, D., Stagiopoulos, P., Aleksić, V. (2020). Advanced Technologies and Standards for Interactive Educational Television. Hershey, PA: IGI Global.

[6] Brković A. (2011). Razvojna psihologija. Čačak: Regionalni centar za profesionalni razvoj zaposlenih u obrazovanju.

[7] Bjekić D., Aleksić, V. i Vučetić, M. (2012). Dvodimenzionalni model Blumove taksonomije u nastavi TIO. Tehnika i informatika u obrazovanju, rad štampan u celini, 1-3. јуна 2012., Čačak (66 - 75). Čačak: Fakultet tehničkih nauka u Čačku.

[8] Juranko, G. (2016). Školski projekti: primjeri aktivnog učenja i poučavanja. Diplomski rad. Zadar: Sveučilište u Zadru.

[9] Videnović M., Čaprić, G. (2020). PISA 2018 izveštaj za Republiku Srbiju. Beograd: Institut za psihologiju Filozofskog fakulteta u Beogradu, Zavod za vrednovanje kvaliteta obrazovanja i vaspitanja.

[10] Činko M. (2016). Upotreba informaciono komunikacionih tehnologija u nastavi. Diplomski rad. Sveučilište u Rijeci, Filozofski fakultet u Rijeci.

[11] Gombar, M. (2011). Primena projektne nastave u izučavanju društvenih sadržaja u nižim razredima osnovne škole. Norma, 16(1), 103-114.

[12] Jorgić D. (2013). Tradicionalno i savremeno u intelektualnom vaspitanju. Filozofski fakultet, Univerzitet u Banja Luci.

[13] Todorović K. (2011). Komunikacija kao sredstvo i efekat vaspitanja. Vaspitanje i obrazovanje - časopis za pedagošku teoriju i praksu, 4, 59-69.

[14] Aleksić, V. (2020). iTV: Exposure Risks?. In D. Politis, P. Stagiopoulos, \& V. Aleksić (Eds.), Advanced Technologies and Standards for Interactive Educational Television: Emerging Research and Opportunities (pp. 134-139). Hershey, PA: IGI Global.

[15] Vidaković M. (2011). NET generacija i E - učenje: savremena obrazovna revolucija. Digitalne medijske tehnologije i društveno-obrazovne promene: medijska istraživanja, Zbornik radova V. Novi Sad: Filozofski fakultet, Odsek za medijske studije, str 255-264.

[16] Branković V. (2018). Zavisnost od interneta: simptomi, uzroci, lečenje. Posećeno u junu 2018. https://samoobrazovanje.rs/internet-zavisnost/

[17] Ristić M., Vosika Z. (2011). Primena internet resursa u nastavi kvantnih računara. Tehnologija, informatika i obrazovanje za društvo učenja i znanja, rad štampan u celini 3-5. јyн 2011. Čačak: Tehnički fakultet Čačak.

[18] Kuzmanović D., Pavlović Z., Popadić D., Milošević T. (2019). Korišćenje interneta i digitalne tehnologije kod dece i mladih u Srbiji: rezultati istraživanja Deca Evrope na internetu. Beograd: Institut za psihologiju Filozofskog fakulteta u Beogradu. 